\title{
Author Correction: A scoping review of research funding for small-scale farmers in water scarce regions
}

Vincent Ricciardi (D, Abdrahmane Wane (D), Balsher Singh Sidhu (1), Cecile Godde, Divya Solomon, Ellen McCullough (1),

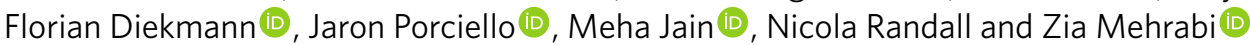

Correction to: Nature Sustainability https://doi.org/10.1038/s41893-020-00623-0, published online 12 October 2020.

In the version of this Article originally published, the name of author Cecile Godde was mistakenly written as Cecile Goode. This has now been corrected.

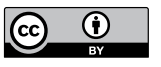

Open Access This article is licensed under a Creative Commons Attribution 4.0 International License, which permits use, sharing, adaptation, distribution and reproduction in any medium or format, as long as you give appropriate credit to the original author(s) and the source, provide a link to the Creative Commons license, and indicate if changes were made. The images or other third party material in this article are included in the article's Creative Commons license, unless indicated otherwise in a credit line to the material. If material is not included in the article's Creative Commons license and your intended use is not permitted by statutory regulation or exceeds the permitted use, you will need to obtain permission directly from the copyright holder. To view a copy of this license, visit http://creativecommons.org/ licenses/by/4.0\%

Published online: 29 October 2020

https://doi.org/10.1038/s41893-020-00639-6

(C) The Author(s) 2020 